\title{
ZEMEPISNÁ A CESTOPISNÁ LITERATÚRA V ŠL̇ACHTICKEJ KNIŽNICI ZIČIOVCOV VO VODERADOCH
}

\author{
Helena Saktorová (Martin)
}

Geographical Literature and Travelogues in the Library of the Aristocratic Ziči Family in Voderady

\begin{abstract}
The Slovak National Archives in Bratislava contain a large manuscript catalogue of an extensive book collection formerly located in one of the numerous residences of the branched aristocratic family Ziči, namely in Voderady near Trnava. The manuscript catalogue, entitled Catalogus Librorum Bibliothecae Vedrodiensis 1894 [A Catalogue of the Books of the Voderady Library 1894], presents a library which, according to information from the 19th century, contained about 12,000 volumes. In the catalogue, the books are divided into 19 thematic groups: theological works and prayer books, linguistic publications, dictionaries and manuals, periodicals, works on arts and crafts, Hungarian novels and short stories, German and Italian novels and short stories, French novels and short stories, English novels and short stories, the works of literature of other European and domestic provenance as well as ancient classics in various editions, memoirs, historical works, geographical literature and travelogues, natural-science publications, works on sports, specialised works on horse breeding, works on economy, legal and political works, and prints referred to as special works.

This paper focuses on the thirteenth thematic group of the Voderady library, namely geographical literature and travelogues (Földrajz, Útleírás). This has been motivated by the fact that members of the Ziči family, the owners of the Voderady residence Jozef Ziči (1841-1924) and his brother Augustín (1852-1925), enjoyed not only travelling around Europe but also exploring distant exotic lands. Consequently, this group contains 717 registered titles, forming the largest group of the Voderady library.

The presented literature in Hungarian, French, English and German comprises a wide range of works including travelogues, atlases and maps, tourist guides, manuals and professional geographical publications of both domestic and foreign provenance.
\end{abstract}

Keywords: catalogues - travelogues - geographical literature - aristocratic libraries - aristocratic Ziči family - Voderady (Trnava district, Slovakia)

Vo fondoch Slovenského národného archívu v Bratislave je uložený objemný rukopisný katalóg bohatej knižnej zbierky, ktorá sa nachádzala $\mathrm{v}$ jednom $\mathrm{z}$ početných sídel rozvetveného šlachtického rodu Ziči vo Voderadoch pri Trnave. Starobylý rod Zičiovcov (Zichy, Zichy-Vasonkeoi...) má svoje korene $\mathrm{v}$ druhej polovici 13. storočia a pôvodne pochádzal zo Somogyskej a Zalskej stolice. Dve hlavné rodové línie z Várpaloty v Mad’arsku a z Rusoviec na Slovensku sa rozčlenili na vedl'ajšie vetvy, prostredníctvom ktorých sa majetky Zičiovcov rozšírili na území Mad’arska, Slovenska, Rakúska a Ukrajiny. Medzi ich známe sídla na Slovensku patrili Rusovce, Voderady, Cífer, Č́ćčov, Divín, Želovce a i. ${ }^{1}$ Viacerí členovia rodu Zičiovcov zastávali významné postavenie v politickom, hospodárskom a kultúrnom živote Uhorska, ako aj Rakúsko-Uhorska. Súčast'ou kultúrneho prostredia zičiovských sídel boli bohaté knižné zbierky, ktoré sa ako celky, prirodzene, nezachovali. Ich existenciu dokumentujú posesorské značky na zachovaných knižných jednotlivinách vo forme rukopisných exlibrisov, heraldických pečiatok, vlepených typografických exlibrisov a d'alších identifikačných signifikantoch. ${ }^{2}$ Významným prameňom pre poznanie knižných zbierok sú aj rodové listinné materiály a katalógy knižných zbierok.

A práve rukopisný knižný katalóg s názvom Catalogus Librorum Bibliothecae Vedrodiensis 1894³ (Katalóg kníh voderadskej knižnice 1894) reprezentuje knižné bohatstvo rodu, uložené v pôvodne neskorobarokovej stavbe, od roku 1878 ranoempírovom dvojpodlažnom trojkrídlovom kaštieli vo Voderadoch pri Trnave, ktorý členovia rodu Ziči obývali $\mathrm{v}$ letných mesiacoch. ${ }^{4}$

Majitelom kaštiel'a v období, ked' bol katalóg vyhotovený, bol verejný činitel', poslanec uhorského snemu Jozef Ziči (1841 - 1924), ktorý bol považovaný za jedného z posledných významných predstavitel'ov voderadskej vetvy Zičiovcov. Narodil sa v Bratislave $\mathrm{v}$ rodine diplomata a stoličného hodnostára Františka Zičiho (1811 - 1900) a grófky Márie Kláry

GUDENUS 1998, s. 343-380.

2 SAKTOROVÁ 2010.

3 Slovenský národný archív, Bratislava. Ministerstvo vnútra SR. Rod Zichy-Voderady, č. 35/9; prepísaný katalóg je dostupný v elektronickej forme na webovej stránke Slovenskej národnej knižnice. SAKTOROVÁ 2018 [online]. Dostupné z: https://www.snk.sk/images/Edicna_cinnost/Katalog_ ZiCi imp.pdf [cit. 10. 11.2021].

${ }_{4}^{4}$ JAKÄBŚICOVÁ - JANURA 2017. 
Demblinovej (1814 - 1868). Jeho súrodencami boli diplomat Teodor (1847 - 1927), cirkevný hodnostár František (1852 - 1883) a historik umenia Augustín (1852 - 1925).

Jozef Ziči študoval na vyššom katolíckom gymnáziu v Trnave, potom právo v Bratislave a vo Viedni. V rokoch 1867 - 1869 pôsobil na ministerstve pol'nohospodárstva, priemyslu a obchodu v Budapešti, bol guvernérom Rjeky, v rokoch 1872 - 1874 minister pol'nohospárstva, v rokoch 1873 - 1875 minister práce a dopravy v Budapešti. V rokoch 1889 - 1893 zastával funkciu bratislavského a v rokoch 1891 - 1893 trenčianskeho župana. Poslancom uhorského snemu a členom jeho hornej snemovne bol v rokoch 1868 - 1870, 1872 - 1875. Po roku 1893 sa stiahol z verejného života a venoval sa hospodáreniu na voderadskom majetku. ${ }^{5} \mathrm{~V}$ roku 1878 sa v Budapešti oženil s kňažnou Ilonou Odescalchiovou (1859 - 1932). V roku 1880 sa im narodil syn Július (umrel v roku 1930) a v roku 1883 sa narodila dcéra Klára (umrela 1971). Klára sa v roku 1907 vo Voderadoch vydala za grófa Štefana Kegleviča (1880 - 1962). V roku 1895 sa Jozef Ziči rozviedol s kňažnou Odescalchiovou a v Bratislave sa oženil s Máriou, rodenou Posch (1875 - 1945), s ktorou mal dcéru Martu (nar. 1908). ${ }^{6}$ Jozef Ziči umrel v roku 1924 vo Voderadoch a je pochovaný v miestnej rodinnej krypte. Poslednými obyvatel'mi voderadského kaštiel'a bola rodina Kláry a Štefana Kegleviča, ktorá v roku 1945 pred príchodom sovietskych vojsk opustila Voderady.

Knižnica bola uložená vo voderadskom kaštieli a podl'a dobových informácií z 19. storočia, mala okolo 12000 zväzkov. Obraz o knižnici z roku 1894 podáva predmetný katalóg s 532 stranami (nie všetky strany sú popísané). Za farebným titulným listom so zičiovským erbom nasleduje obsah katalógu. Arabskými číslami je označené poradie 19 tematických skupín so slovným pomenovaním danej skupiny v mad'arčine. V prvej skupine sú zapísané teologické práce a modlitebné knižky, v druhej jazykovedné publikácie, v tretej slovníky a príručky, v štvrtej sú uvedené periodiká, piata zaznamenáva diela o umení a remeslách, šiesta uvádza mad'arské romány a poviedky, siedma nemecké a talianske romány a poviedky, ôsma francúzske romány a poviedky, deviata anglické romány a poviedky, v desiatej sú zapísané diela krásnej literatúry európskej i domácej proveniencie, ako aj antických klasikov v rozličných edíciách. V jedenástej skupine sú zaevidované memoáre, v dvanástej sa nachádzajú historické práce, $v$ trinástej zemepisná literatúra a cestopisy, v štrnástej odborné publikácie z oblasti prírodných vied, v pätnástej práce o športe, v šestnástej špecializované diela o chove koní, do sedemnástej skupiny sú zaradené práce týkajúce sa hospodárstva, v osemnástej sú právnické a politické diela a napokon v devätnástej skupine sú uvedené tlače označené ako zvláštne diela. Jednotlivé tituly kníh sú $\mathrm{v}$ rámci tematických skupín zapísané $\mathrm{v}$ abecednom poriadku podl'a autorov alebo názvov anonymných diel, potom nasleduje názov diela, počet exemplárov kníh v knižnici, d'alej miesto a rok vydania knihy a napokon na poslednom mieste signatúra tvorená numericko-alfabetickou kombináciou, čo bolo zároveň aj schémou uloženia kníh v skriniach knižnice. Všetky tieto údaje sú zapísané úhl’adným a dobre čitatel'ným rukopisom do kolóniek v rámci nalinkovaných listov katalógu. Záznamy v jednotlivých tematických skupinách sú číslované priebežne poradovým číslom, v sumárnom počte ide o 3993 očíslovaných titulov, zároveň sú v katalógu zapísané aj záznamy bez poradového čísla.

$\mathrm{V}$ našom príspevku sme upriamili pozornost' na trinástu tematickú skupinu voderadskej knižnice o zemepisnej literatúre a cestopisoch (Földrajz, Útleírás), ${ }^{7}$ vychádzajúc z poznania, že Jozef Ziči a jeho brat Augustín mali zálubu v cestovaní nielen po Európe, ale aj v poznávaní vzdialených exotických krajín. Ich cesty, poznačené súkromnými záujmami, súviseli pravdepodobne aj s ich diplomatickými misiami, či profesnými povinnost'ami vysoko postavených hodnostárov. Tomuto by zodpovedalo aj výrazné zastúpenie zemepisnej a cestopisnej literatúry vo fonde knižnice v počte 717 zapísaných titulov (vyše 1100 knižničných jednotiek), čo predstavuje najväčšiu čast' voderadskej knižnice. Z typologického hl'adiska ide o knižné publikácie, periodiká a možno aj o fotografické súbory. Akvizičné aktivity majitel'ov knižnice nateraz nepoznáme, nie je známe ako prebiehalo doplňovanie knižnice, ktorej obraz z roku 1894 odzrkadl'uje zachovaný katalóg (so sporadickými dodatkami z roku 1895). Z chronologického pohl'adu vel'ká väčšina vydaní pochádza z 19. storočia. Najstaršou publikáciou v tomto súbore je frankfurtské vydanie práce švajčiarskeho kartografa, vydavatel'a a grafika Matthausa Meriana (1593 - 1650) s názvom Topographia Provinciarum Austricarum z roku $1649,{ }^{8}$ najviac vydaní pochádza z roku 1876 a 1877, teda z obdobia, kedy Jozef Ziči so svojím bratom Augustínom podnikli v roku 1875 - 1876 cesty po východnej Ázii a v roku 1877 navštívili americké mestá. Priebeh cesty si Jozef Ziči dôkladne denne zapisoval do denníkov v mad'arčine, ktoré boli takisto zaznamenané v katalógu knižnice; pod číslom 714 je zaevidovaný denník z Ameriky: 1877-iki Amerikai Utazásom Naplója a pod číslom 715 je zapísaný denník z ciest po východnej Ázii: Ázsiai Utazásom Naplója. Oba denníky vyšli tlačou. Z iniciatívy vedenia Západoslovenského múzea bol Zičiho denník z ázijskej cesty prepísaný, preložený do slovenčiny a roku 2006 vydaný v Trnave pod názvom Denník Jozefa Zičiho z cesty po východnej Ázii v rokoch 1875 - $1876 .{ }^{9}$ V roku 2013 v Mad'arskej národnej knižnici (Országos Széchényi Könyvtár) v Budapešti vydali oba denníky v dvojzväzkovej publikácii s názvom Gróf Zichy József utazásai. ${ }^{10}$

Cestu do východnej Ázie bratia Zičiovci začali 23. novembra 1875 odchodom z Voderád do Viedne. Odtial' 24. novembra pokračovali do Bukurešti, cez Konstantinopol do Alexandrie, Káhiry cez Suezský prieplav do Červeného

\footnotetext{
${ }^{5}$ ČAMBÁLOVÁ 1993, s. 27; Slovenský biografický slovník 1994, s. 444 - 445.

${ }^{6}$ GUDENUS 1993, s. 359.

${ }^{7} \mathrm{~V}$ pôvodnom katalógu knižnice je zemepisná a cestopisná literatúra zapísaná na stranách 310 - 378. Citované práce uvádzame podla katalógu a v našom texte označíme heslom Katalóg s príslušným číslom.

${ }^{8}$ Katalóg, č. 417.

${ }^{9}$ ZIČI 2006; originál denníka je uložený v Slovenskom národnom archíve v Bratislave.

${ }^{10}$ ZICHY 2013.
} 
mora a odtial' do Indického oceánu na ostrov Ceylon, kde sa zdržiavali do 31. decembra 1875. Potom sa doplavili do Indonézie na ostrov Jávu, pokračovali do Bangkoku v Thajsku. Ďalším ciel'om ich cesty bola Čína. V čase od 22. marca do 11. mája sa zdržiavali na polostrove Macao, potom navštívili Hongkong a d'alšie čínske lokality, napr. Canton, Woosung, Šanghaj, Nanking a i. V nasledujúcom čase sa preplavili do Japonska, kde navštívili Nagasaki, Jokohamu, Tokio a i. Z Japonska prešli do Pekingu. Odtial' ich cesta viedla smerom do Mongolska, v dňoch 27. až 31. júla absolvovali prechod cez púšt' Gobi. Ich putovanie pokračovalo cez mongolské územie smerom na Sibír. Cestu cez Sibír absolvovali v niekol'kých etapách: Kiachta Irkutsk - Krasnojarsk - Tomsk - Jekaterinburg - Perm Nižný Novgorod. Z Nižného Novgorodu prišli do Moskvy, odkial' smerovali do Varšavy, Krakova a napokon do Viedne. Jozef a Augustín Ziči prišli domov do Voderád 21. septembra 1876. Posledné zápisy v cestovatel’skom denníku Jozefa Zičiho sú datované 22. septembra 1876 vo Voderadoch.

Bohatá zemepisná a cestopisná literatúra vo voderadskom kaštieli mala dôležité miesto pre majitel'ov, čo dokumentuje názor Jozefa Zičiho, prezentovaný v úvode denníka: „Nejdeme do neznámych provincií, nepodnikáme objavitelskú cestu, miesta, ktoré navštívime, sú už opísané v zaujímavých prácach. To znamená, čo si môžem prečitat', to už netreba opisovat', ale nechcem zabudnút' na svoje impresie... "11 Podl'a zmienok v denníku sa Jozef Ziči cielene venoval štúdiu odbornej literatúry, cituje napr. prácu o Siame, Barme, Kambodži a Číne The Land of White Elephant od amerického cestovatel'a Franka Vincenta ml. (1848 - 1916), ${ }^{12}$ prácu Aimé Humberta-Droza (1819 - 1900) o Japonsku Le Japon Illustré a i., ${ }^{13}$ tieto práce sú zapísané v katalógu knižnice. Udržiaval zrejme kontakt s kníhkupectvom G. Kolff and Co. v Jakarte, súdiac podl'a kníhkupeckého reklamného štítka, ktorý bol umiestnený v Zičiho denníku. ${ }^{14}$ Denník, okrem podrobných údajov o ceste Zičiovcov, je prameňom aj pre poznanie vzt'ahu Zičiho ku knihám vôbec a dokumentuje jeho kultúrnu rozhl'adenost'.

Zemepisná a cestopisná literatúra orientovaná na cestovatel'ské aktivity Zičiovcov je prezentovaná širokou škálou autorov domáceho i zahraničného pôvodu. Z prác uhorských cestovatel'ov sa v tomto súbore nachádzala dvojzväzková publikácia grófa Emanuela Andrášiho (1821 - 1891), ${ }^{15}$ príslušníka betliarskej vetvy šl'achtického rodu, v ktorej opísal zážitky zo svojej cesty do Indie, Číny, Indonézie a Srí Lanky, realizovanej po roku 1849. Práca vyšla v Pešti roku 1853 pod názvom Utazás Kelet Indiákon. ${ }^{16} \mathrm{~V}$ cisársko-král'ovských diplomatických službách pôsobil Gejza Bernáth (1845 - 1882). Slúžil v Lisabone, Londýne, Paríži, Petrohrade a Pekingu. Bol členom Rakúsko-uhorskej východoázijskej expedície. Poznatky z ciest publikoval v práci Keletázsiai utazás (Pest 1873). ${ }^{17}$ Jozef Ziči mal k dispozícii aj tlačou vydaný cestovatel'ský denník od autora Szilárda Blánu, ktorý bol účastníkom revolúcie 1848 - 1849, najprv slúžil v cisársko-král'ovskej armáde, potom prešiel k honvédom. Neskôr ako emigrant precestoval Európu, Áziu a Afriku. Zážitky a dobrodružstvá z ciest uverejnil v publikácii Három világrészben (Pest 1872). ${ }^{18}$ Vo voderadskej knižnici sa nachádzala práca významného geológa, geografa a univerzitného profesora, bratislavského rodáka Ludovíta Lóczyho $\left(1849\right.$ - 1920). ${ }^{19} \mathrm{~V}$ rokoch 1877 - 80 sa zúčastnil na výskumnej expedícii grófa Bélu Széchényiho do východnej Ázie. ${ }^{20}$ Svoje vedecké poznatky, ako aj výskumy menovanej expedície zhrnul v uznávaných publikáciách, $\mathrm{z}$ nich mal gróf Ziči k dispozícii prácu s názvom $A$ Khinai birodalom leirása (Budapest 1886). ${ }^{21}$ Expedície do východnej Ázie sa týkala aj práca jej d'alšieho účastníka, rakúskeho dôstojníka, geografa, diplomata a kartografa Gustava Ritter von Kreitnera (1847 - 1893), ktorý tu pôsobil najmä ako kartograf. Aj jeho dielo s názvom Im fernen Osten (Wien $1881)^{22}$ sa nachádzalo vo voderadskej knižnici. Mad'arský lekár a cestovatel' Ferencz Gáspár $(1861 \text { - 1923) })^{23}$ ako lodný lekár precestoval okrem Antarktídy všetky svetadiely a svoje skúsenosti zdokumentoval vo viacerých prácach, vo voderadskom sídle sa zachovala jeho prvá publikácia Negyvenezer mértföld vitorlával és gözzel (Szeged 1892). ${ }^{24}$

Kaštiel’nu knižnicu zapíňali okrem domácej cestopisnej literatúry d'alej práce európskych cestovatel'ov, objavitel'ov, vedcov, diplomatov a i. Francúzsky cestovatel' Ludovic de Beauvoir (1846 - 1929) v rokoch 1865 - 1867 uskutočnil cestu do Austrálie, východnej Indie, Thajska, Č́ny, Japonska a Spojených štátov. Zo svojej cesty publikoval trojzväzkové dielo, ktoré vyšlo v roku 1867, 1872. Vo Voderadoch sa nachádzalo parížske vydanie z rokov $1874,1875 .{ }^{25}$ Ďalšia kniha o d'alekom Východe $\mathrm{v}$ menovanej knižnici pochádzala z pera francúzskeho právnika Georgesa Bousqueta (1846 - 1937), ktorý sa zaoberal trestným a hospodárskym právom. Od roku 1872 pôsobil štyri roky ako diplomat v Japonsku, kde spolupracoval na tvorbe článkov občianskeho práva. Z japonského pobytu napísal knihu Le Japon

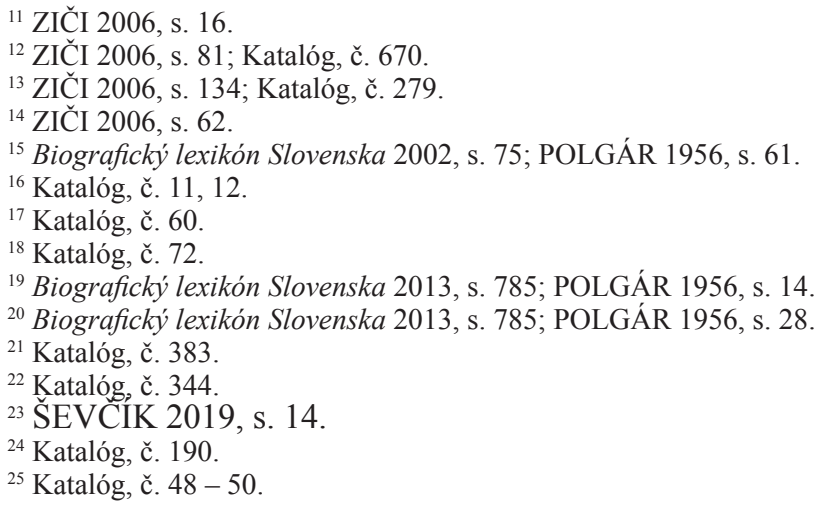


de Nos Jours (Paris 1877). ${ }^{26}$ Americký prírodovedec Albert Smith Bickmore $(1839$ - 1914) v roku 1865 - 1866 podnikol expedíciu do Východoindického súostrovia, ktorú opísal v Reisen im Ostindischen Archipel (Jena 1869). ${ }^{27}$ Francúzsky novinár Edmond Cotteau (1833 - 1896), spolupracovník novín Le Temps a Le Tour du Monde, v rokoch 1876 - 1877 cestoval do Ameriky a Indie, v rokoch 1878 - 1879 navštívil strednú Európu, Japonsko a v rokoch 1881 - 1882 sa vrátil do Číny a Indočíny. V rokoch 1883 - 1884 uskutočnil cestu okolo sveta. Publikoval cestopisné poznámky, z nich sa vo voderadskej knižnici nachádzajú tituly De Paris au Japon (Paris 1883), ${ }^{28}$ Promenade dans L'Inde et a Ceylon (Paris 1880). ${ }^{29}$ Francúzsky priemyselník Émile Étienne Guimet (1836 - 1918) sa venoval aj cestovaniu, ministrom školstva bol poverený, aby študoval náboženstvo Ďalekého východu. Ako výsledok expedície sústredil zbierku japonského a čínskeho porcelánu, založil Museé Guimet so sídlom v Lyone. Opis japonskej spoločnosti priblížil v práci Promenades Japonaises (Paris 1878, 1880). ${ }^{30}$ Americký spisovatel', maliar, vojak a cestovatel' nemeckého pôvodu Peter Bernhard Wilhelm Heine $(1827$ - 1885) v roku 1848 odišiel ako emigrant do Ameriky. Popri umeleckej činnosti cestoval po Japonsku a Východnej Ázii. Svoje poznatky zaznamenal v memoároch, z nich sa vo voderadskej knižnici nachádzali práce Japan und Seine Bewohner (Leipzig), ${ }^{31}$ Die Expedition in die Seen von China Japan (Leipzig 1858) ${ }^{32}$ a Eine Weltreise um die Nördliche Hemisphäre. (Leipzig 1869). ${ }^{33}$ Vo Voderadoch Jozef Ziči študoval, ako sme vyššie uviedli, prácu švajčiarskeho politika a cestovatela Aimé HumbertDroza (1819 - 1900). Viedol prvú švajčiarsku diplomatickú misiu v Japonsku a podpísal prvú obchodnú dohodu mezi Švajčiarskom a Japonskom, čo zdokumentoval v práci $L e$ Japon Illustré (Paris 1870). Ďalším autorom v knižnici bol Wilhelm Joest $(1852$ - 1897), nemecký etnograf a cestovatel'. K jeho cestovatel'ských destináciám patrila severná Afrika, potom v rokoch 1876 - 1879 Severná a Južná Amerika, Kanada. V rokoch 1879 - 1881 cestoval po južnej a východnej Ázii. Zdržiaval sa aj v Japonsku, odkial' sa v roku 1881 cez Mongolsko a Sibír vrátil do Nemecka. Zážitky z cesty publikoval knižne pod titulom Aus Japan nach Deutschland durch Sibirien (Köln 1887) ${ }^{34}$ Francúzsky cestovatel' a spisovatel' Victor Edmond Meignan (nar. 1846) podnikol cestu z Paríža cez Petrohrad do Moskvy, precestoval Sibír, pokračoval do Mongolska, potom do Pekingu. Do Francúzska sa vrátil cez Jokohamu, San Francisco a New York. Svoje pozorovania z tejto cesty uverejnil v knihe De Paris a Pekin par terre Siberie-Mongolie. ${ }^{35}$ Parížske vydanie $\mathrm{z}$ roku 1877 , ktoré je zapísané v katalógu voderadskej knižnice. V tomto katalógu sú uvedené aj práce ruského geografa a objavitela stredovýchodnej Ázie Nikolaja Michajloviča Prževalského $(1839-1888)^{36}$ v nemeckom preklade: Reisen in der Mongolei. (Jena 1877), ${ }^{37}$ Reisen in Tibet (Jena 1884) ${ }^{38}$ Absolvoval niekol'ko výskumných expedícií v menovanej oblasti. Prispel k obohateniu európskych vedeckých poznatkov zo strednej Ázie. Počas výprav sa venoval aj flóre a faune skúmaného prostredia.

Bratia Jozef a Augustín Ziči postupovali na svojej ceste z Číny cez Mongolsko, Sibír, Rusko a cez Pol'sko domov do Voderad. S týmto úsekom putovania bratov Zičiovcov tematicky súvisia cestopisy a práce o Sibíri, ázijskej a európskej časti Ruska. Cestovatel' z Hurbanova Ján Karol Beše $(1765-1838)^{39}$ precestoval Kaukaz, východnú Áziu a bol na Madagaskare, v rokoch 1790 - 1824 žil v Gruzínsku. Cestu na Krym, Kaukaz a Gruzínsko opísal vo francúzskej práci Voyage en Crimeé au Caucase au Géorgie (Paris 1838) ${ }^{40}$ Joseph Billings $(1761$ - 1806) kapitán v ruskom námorníctve, zúčastnil sa viacerých expedícií v oblasti severovýchodného Ruska. Svoje poznatky z expedícií publikoval v práci, ktorá vyšla v Paríżi 1802 Voyage dans le Nord de la Russie Asiatique. ${ }^{41}$ Od Vasilija Michajloviča Golovnina (1776 - 1831), ruského námorníka, cestovatel'a a člena Ruskej akadémie vied, mali vo Voderadoch jeho cestopisy Voyage de M. Golovnin (Paris 1818). ${ }^{42}$ Cesty po južnej časti Ruska predstavil ruský obchodník, diplomat Anatole Nikolajevič Demidoff $(1813-1870)$ v práci Voyage dans la Russie meridionale (Paris 1854). ${ }^{43}$

Americký objavitel' Georg Kenann (1845 - 1924) sa venoval výskumu Ruska. Precestoval Sibír, juhovýchodné a severovýchodné oblasti Ruska. Cestovatel'ské a objavné poznatky uverejnil vo viacerých publikáciách, z nich vo Voderadoch mali dva tituly o Sibíri Zeltleben in Sibirien, Sibirien (Berlin 1890). ${ }^{44}$ O Sibíri publikoval

\footnotetext{
${ }^{26}$ Katalóg, č. 81 .

${ }^{27}$ Katalóg, č. 65.

${ }^{28}$ Katalóg, č. 121.

${ }^{29}$ Katalóg, č. 122.

${ }^{30}$ Katalóg, č. 226, 227.

${ }^{31}$ Katalóg, č. 248.

${ }^{32}$ Katalóg, č. 249.

${ }^{33}$ Katalóg, č. 247.

${ }^{34}$ Katalóg, č. 304.

${ }^{35}$ Katalóg, č. 416.

${ }^{36}$ POLGAR 1956, s. 36.

${ }^{37}$ Katalóg, č. 519.

${ }^{38}$ Katalóg, č. 520

${ }^{39}$ Biografický lexikón Slovenska 2002, s. 399.

${ }^{40}$ Katalóg, č. 62.

${ }^{41}$ Katalóg, č. 67.

${ }^{42}$ Katalóg, č. 200.

${ }^{43}$ Katalóg, č. 141.

${ }^{44}$ Katalóg, č. 321, 322.
} 
práce aj francúzsky spisovatel' Ferdinand Tugnot de Lanoye $\left(1810\right.$ - 1870) s názvom La Sibérie (Paris 1865, 1868) ${ }^{45}$ ako aj britský kňaz Henry Lansdell (1841 - 1919), ktorý vykonal cestu z Európy, cez Afriku do Ázie. Svoje skúsenosti a poznatky $\mathrm{z}$ ciest zaznamenal vo viacerých prácach, $\mathrm{z}$ nich sa vo voderadskej knižnici zachovali nemecké preklady Russisch Central Asien. (Leipzig 1885), Durch Sibirien (Jena 1882). ${ }^{46}$ Nórsky vedec, hvezdár a geofyzik Christopher Hansteen (1784 - 1873) sa zúčastnil výskumnej expedície v západnej Sibíri. Z jeho publikovaných zápisov o tejto expedícii vo Voderadoch mali prácu $\mathrm{v}$ nemeckom preklade Reise Erinnerungen aus Sibirien (Leipzig 1854). ${ }^{47}$ Súčast'ou voderadskej knižnice s cestovatel'ským a geografickým obsahom boli aj publikované denníky $\mathrm{z}$ ciest od agronóma, diplomata, cestovatel'a z moravských Kvasíc Maximiliana von Proskowetz (1851 - 1898). V roku 1880 precestoval Egypt, Palestínu, Sýriu, Malú Áziu a v roku 1888 navštívil Kaukaz a mestá Samarkand a Bucharu, čo priblížil v publikácii s názvom Vom Newastrand nach Samarkand (Wien 1889). ${ }^{48}$

Jozef a Augustín Ziči v roku 1877 v rámci svojich cestovatel'ských plánov, navštívili Ameriku a to nasledovné mestá a destinácie: New York - Niagarské vodopády - jazero Ontario - New York - Long Island - južné a východné pobrežie Vel'kých jazier - San Francisco a jeho okolie -Saint Louis - Pittsburg - Washington - New York. V katalógu voderadskej knižnice bolo zapísaných okolo 100 titulov publikácí́ tematicky zameraných na americké štáty od domácich i zahraničných autorov. Z nich spomenieme autora Eugena Bánóa z Rožkovian (1855 - 1927), ${ }^{49}$ ktorý precestoval takmer celý svet, potom sa usadil v rokoch 1903 - 1910 v Mexiku, neskôr žil v Egypte, počas druhej svetovej vojny v Barcelone. Jeho cestopisy vyšli v Budapešti ako Utiképek Amerikából (Budapest 1890). ${ }^{50}$ Sándor Farkas (1795 - 1842) spisovatel', prekladatel', cestovatel', člen vedeckých spoločností v Uhorsku navštívil mestá v Spojených štátoch amerických a Kanade. Cestopis Utazás Észak-Amerikában, ${ }^{51}$ v ktorom si všímal aj spoločenské pomery navštívených destinácií, pôvodne vyšiel v Kolozsvári roku 1834. Vo voderadskej knižnici bolo zaevidované vydanie z roku 1835. Svoju cestu po Amerike zdokumentoval aj profesor chémie, člen Mad'arskej akadémie vied Károly Nendtvich (1811 - 1892) V práci Amerikai utazásom (Pest 1858). ${ }^{52}$ Mad'arský prírodovedec, etnograf, cestovatel' a člen Mad'arskej akadémie vied János Xantus (1825 - 1894) roku 1852 emigroval do Ameriky, kde sa zúčastňoval vedeckých expedícií.
Z jeho publikačnej tvorby Zičiovci vlastnili prácu o jeho cestách po južnej Kalifornii Utazás Kalifornia déli részeiben (Pest 1860) a o severnej Amerike na základe korešpondencie Levelei Északamerikából (Pest 1858). ${ }^{53} \mathrm{O}$ svojej ceste do Ameriky v roku 1862 v periodikách publikoval aj strážca uhorskej koruny, krajinský hodnostár gróf Béla Széchényi (1837 - 1918); jeho texty boli známe aj vo voderadskej knižnici. Popri cestopisoch o Amerike z pera domácich autorov bohaté zastúpenie $\mathrm{v}$ tejto knižnici mali práce od mnohých európskych autorov-cestovatel'ov. Na tomto mieste upozorníme na prácu francúzskeho filológa J. J. Ampére, ktorý cestoval po Afrike a Amerike a publikoval svoje zážitky v titule Promenade en Amerique (Paris 1874). ${ }^{54}$ Svoje cestovanie po Amerike zaznamenala aj francúzska spisovatel'ka Olympe Audouard v titule A Travers l'Amerique. (Paris 1871), ${ }^{55}$ ktorý bol k dipozícii pre obyvatel'ov kaštiel'a. V knižnici stáli aj zväzky zo série cestopisov, ktoré vydával kapitán Basil Hall $(1788$ - 1844), z nich Zičiovci mali francúzske cestopisy z Chile, Peru a Mexika, ako aj Spojených štátov amerických (Paris 1834). Po Mexiku cestovala grófka Paula Kolonitz ${ }^{56}$ a z cesty uverejnila prácu v nemčine Eine Reise nach Mexico (Wien 1867). O svojich cestách v Spojených štátoch, Kanady a Mexika napísal barón von Müller Reisen in den Vereinigten Staaten, Canada und Mexico (Leipzig 1864), ${ }^{57}$ d'alej Max von Thielmann $\mathrm{v}$ Lipsku publikoval dielo o svojich štyroch cestách v nemčine Vier Wege durch Amerika (Leipzig 1879).$^{58}$ Obraz o Spojených štátoch, Kanade, Južnej Amerike a ich jednotlivých regiónoch sa odzrkadl'uje v d'alších, odborných prácach so spoločensko-politickým, etnografickým a jazykovedným zameraním, obrazových publikáciách, ako aj špecializovaných príručkách a turistických sprievodcoch po regiónoch, národných parkoch či amerických mestách. Pochádzajú najmä z produkcie newyorského vydavatel'stva Appleton \& Company of New York, napr. ilustrované príručky pre americké rekreačné zariadenia Illustrated Hand-book of American Summer Resorts (New-York 1877), americké mestá Illustrated Hand-book of American Cities (New-York 1877), cestovné príručky pre dopravu v severnej, východnej a západnej Amerike Hand-book of American Travel. Northern and Eastern Tour, Hand-book of American Travel. Western Tour (New-York 1876) ${ }^{59}$ a i. Okrem toho vo voderadskej knižnice boli zaradení sprievodcovia miest ako je Chicago, New York a Cincinnati, sprievodcovia pre návštevníkov Niagarských vodopádov (Allen, H. Tunis. Illustrated Guide to Niagara. 1877; ${ }^{60}$ Hunter, W. M. S.

\footnotetext{
${ }^{45}$ Katalóg, č. 358, 359.

${ }^{46}$ Katalóg, č. 360, 361.

${ }^{47}$ Katalóg, č. 235.

${ }^{48}$ Katalóg, č. 519.

${ }^{49}$ Biografický lexikón Slovenska 2002, s. 212.

${ }^{50}$ Katalóg, č. 40.

${ }^{51}$ Katalóg, č. 169.

${ }^{52}$ Katalóg, č. 453.

${ }^{53}$ Katalóg, č. 705, 706.

${ }^{54}$ Katalóg, č. 9.

${ }^{55}$ Katalóg, č. 27.

${ }_{56}$ ŠEVČİK 2019, s. 14; Katalóg 27.

${ }^{57}$ Katalóg, č. 42.

${ }^{58}$ Katalóg, č. 637.

${ }^{59}$ Katalóg, č. $16-20$.

${ }^{60}$ Katalóg, č. 4.
} 
Panoramiac Guide from Niagara-Falls to Quebec. Montreal $1869)^{61}$, národného parku Yosemite v Kalifornii (Whitney. The Yosemite Guide Book. 1870;62 Tourist's Guide Yosemite. San Francisco 1871), jazera George (Stoddard, S. R. Lake George. Albany 1876), publikácie o plavbách na amerických riekach (The Hudson River by Pen and Pencil. New York 1888; Missisippi-Fahrten. Leipzig 1881). ${ }^{63}$

V príspevku sme poukázali na čast' cestopisov tematicky súvisiacich so vzdialenými a exotickými zámorskými destináciami, ktoré navštívili bratia Jozef a Augustín Ziči. Je však známe, že najmä Jozef Ziči navštívil aj mnohé európske štáty, čo vyplývalo z jeho kariérnych povinností, či osobných záujmov. V katalógu voderadskej knižnice sú zaevidované početné vydania turistických sprievodcov známeho nemeckého autora a vydavatel'a Karla Baedekera (1801 - 1859). Ide o turistických sprievodcov Severnej Ameriky, Talianska, Švajčiarska, Belgicka a Holandska, Rakúsko-Uhorska, Sedmohradska a Nemecka. ${ }^{64}$ Slovenského teritória sa týkajú napr. práce polyhistora Mateja Bela (1684 - 1749) Notitia Hungariae (Viedeň 1735), ${ }^{65}$ atlas lexikografa a geografa Jána Mateja Korabinského $\left(1740\right.$ - 1811), ${ }^{66}$ známy cestopis vlastivedného pracovníka a publicistu Alojza Medňanského Malerische Reise auf dem Wagfluisse. (Pest 1844), ${ }^{67}$ turistických sprievodcov po Považí od pedagóga Adolfa Pechánya (1859 - 1942): Kalauz a Vágvölgyében; Touristen Ausfluge in der Kleinen Fatra (Budapešt' 1888, 1889), ${ }^{68}$ turistického sprievodcu po Vysokých Tatrách od kartografa a pedagóga Karola Kolbenheyera (1841 - 1901) A Magas Tátra (Tešín 1883), ${ }^{69}$ ako aj práce o Bratislave a jej okolí autorov Paula Ballusa, Alexandra Hekscha a i.

Na záver možno stručne konštatovat', že žánrovú a obsahovú pestrost' cestopisnej a zemepisnej literatúry v mad'arčine, francúzštine, angličtine a nemčine, zaznamenanej v katalógu zičiovskej knižnice vo Voderadoch možno na tomto mieste charakterizovat' len v hrubých kontúrach. Prezentovaná literatúra predstavuje bohatú škálu diel cestopisov, atlasov a máp, turistických sprievodcov, príručiek a odborných geografických publikácií domácej i zahraničnej proveniencie.

Aj táto literatúra, spolu s bohatstvom diel z ostatných 18 tematických skupín knižnice, predstavovala mimoriadne cennú zbierku kníh z najrozličnejších odborov dobovej spisby v širších uhorských a európskych súvislostiach. Vzácna a bohatá knižnica voderadského sídla Zičiovcov sa ako celok nezachovala. $\mathrm{V}$ doterajšom výskume sa nám podarilo identifikovat' jediný titul - viacjazyčný slovník talianskeho humanistu Ambrogia Calepina (Katalóg 3/11) z roku 1592, ktorý sa nachádza vo fondoch Univerzitnej knižnice v Bratislave. Na titulnom liste slovníka sa nachádza pečiatka s erbom Zičiovcov, identická s pečiatkou umiestnenou v predmetnom katalógu. Hlbšie poznanie dejín a osudov knižnice si vyžaduje d’alšie posesorské a archívne bádanie.

\section{Archívne pramene:}

Slovenský národný archív, Bratislava. Ministerstvo vnútra SR. Rod Zichy-Voderady, č. 35/9.

\section{Zoznam použitej literatúry:}

Biografický lexikón Slovenska. I. Martin: Slovenská národná knižnica, Národný biografický ústav, 2002.

ČAMBÁLOVÁ 1993: ČAMBÁLOVÁ, Daniela et al. Voderady 1243 - 1993. Voderady: Obecný úrad Voderady, 1993.

GUDENUS 1998: GUDENUS, J. J. A magyarországi fónemesség XX. századi genealogiája. IV. kötet (Sz-Zs). Budapest: Heraldika, 1998.

JAKABŠICOVÁ 2017: JAKABŠICOVÁ, Alexandra JANURA, Tomáš. Historický park vo Voderadoch - ako prinavrátit' jeho dávnu noblesu. Monument revue: časopis Pamiatkového úradu na propagáciu vedeckého poznávania pamiatkového fondu Slovenska 6, 2017, č. 2, s. 13 - 17.

Magyar életrajzi lexikon. 1 - 3. Budapest: Akadémiai kiadó, 1981, 1982.

POLGÁR 1956: POLGÁR, Erzsébet - TISZAY, Andor. Utazások a nagyvilágban. Budapest: Fővárosi Szabó Ervin Könyvtár, 1956.

SAKTOROVÁ 2010: SAKTOROVÁ, Helena. Knižné zbierky rodu Ziči. In: Kniha 2010. Zbornik o problémoch a dejinách knižnej kultúry. Martin: Slovenská národná knižnica, 2010, s. 179 - 184.

Slovenský biografický slovník. VI. Martin: Matica slovenská, 1994.

SAKTOROVÁ 2018: SAKTOROVÁ, Helena (ed.). Katalóg kníh zičiovskej bibliotéky vo Voderadoch z roku 1894. Martin: Slovenská národní knižnica, 2018. Dostupné z: https://www.snk.sk/images/Edicna_cinnost/Katalog_ZiCi_ imp.pdf [cit. 10. 11. 2021].

ŠEFČÍK 2019: ŠEFČÍK, Milan. Objavitelia a cestovatelia. Cestopisy z historickej knižnice Západoslovenského múzea. Trnava: Trnavský samosprávny kraj-Západoslovenské múzeum, 2019.

ZIČI 2006: ZIČI, Jozef. Denník grófa Jozefa Zičiho z cesty po východnej Ázii v rokoch 1875 - 1876. Trnava: Trnavský samosprávny kraj-Západoslovenské múzeum, 2006.

ZICHY 2013: ZICHY, József. Gróf Zichy József utazásai. I. - II. Budapest: Széphalom Könyvmühely, Országos Széchényi könyvtár, 2013.

\footnotetext{
${ }^{61}$ Katalóg, č. 283.

${ }^{62}$ Katalóg, č. 693.

${ }^{63}$ Katalóg, č. 276, 261.

${ }^{64}$ Katalóg, č. $28-35$.

${ }^{65}$ Katalóg, č. 53.

${ }^{66}$ Katalóg, č. 341.

${ }^{67}$ Katalóg, č. 415

${ }^{68}$ Katalóg, č. 494, 495.

${ }^{69}$ Katalóg, č. 337.
} 


\section{Internetové zdroje:}

Genealogy.eu [online]. Dostupné z: http://genealogy.euweb. cz/hung/keglevich4.html [cit. 10. 11. 2021]

Magyar Elektronikus Könyvtár [online]. Dostupné z: http:// mek.oszk.hu/03630/html [cit. 10. 11. 2021].

Arcanum [online]. Dostupné z: https://www.arcanum.com/ en/online-kiadvanyok [cit. 10. 11. 2021].

Catalogue SUDOC [online]. Dostupné z: http://www.sudoc.abes.fr/cbs/xslt $/$ ? COOKIE $=U 10178$ [cit. 10. 11. 2021].

Wikipédia. Slobodná encyklopédia [online]. Dostupné z: https://sk.wikipedia.org/ [cit. 10. 11. 2021].

\section{Helena Saktorová}

Devínska 21

03608 Martin 